\title{
Impact of Arenicola marina on bacteria in intertidal sediments
}

\author{
Sönnke Grossmann*, Wolfgang Reichardt \\ Institut für Meereskunde an der Universität Kiel, Düsternbrooker Weg 20, W-2300 Kiel, Germany
}

\begin{abstract}
On intertidal flats of the North Frisian Wadden Sea, total abundance and biomass of bacteria were examined at 6 sites in the particle transport system of Arenicola marina burrows. Both bacterial abundance and biomass showed maxima on the input side, with distinctive peaks in the polychaete's foregut (oesophagus), and declined on the egestive side (hindgut and fecal casts) by $70 \%$. Cell sizes did not differ significantly among sampling sites. In feeding experiments using fluorochromelabelled (killed) bacteria and indigestible fluorescent particles as a reference standard, disappearance rates of total bacterial biomass were 80 to $90 \%$. Gut extracts showed lysozyme activity. Peaks of bacterial densities in sediment samples from the foregut region that did not appear in the feeding experiments with killed bacteria suggest 'gardening' Despite high variances, decreasing viable counts of bacteria on nutrient agar noted between paired foregut and hindgut samples indicated selective survival.
\end{abstract}

\section{INTRODUCTION}

Reworking of sediments by benthic subsurface deposit feeders is believed to enhance the rate of various biogeochemical processes of sediment diagenesis (Aller \& Yingst 1978, Hines \& Jones 1985, Reichardt 1988). Furthermore, benthic deposit feeders are regarded as important regenerators of nutrients for pelagic productivity (Doering 1989). The 'funnel-feeding' polychaete Arenicola marina (lugworm) is the most visible cause of bioturbation in intertidal flats of the Wadden Sea. This subsurface bulk ingestor is able to ingest $1 \mathrm{~cm}^{3}$ of sediment $\mathrm{h}^{-1}$ (Cadee 1976). The impact of such intense sediment feeding on biogeochemically active bacteria, however, has still to be quantified. Once ingested, the bulk of bacterial biomass may be removed from the sediment (Baker \& Bradnam 1976, Austin \& Baker 1988). On the other hand, the growth of bacteria surviving the passage through an animal's gut may be stimulated by an increased supply of nutrients in gut and feces as well as by removal of predators, competitors and inhibitors during selective digestion (Newell 1965, Hargrave 1970, Juniper 1981, Deming \& Colwell 1982, Plante et al. 1989).

\footnotetext{
- Present address: Alfred-Wegener-Institut für Polar- und Meeresforschung, Postfach 120161, W-2850 Bremerhaven, Germany
}

In the perizoic niches and microhabitats provided by polychaete burrow systems, positive feed back of macrofaunal deposit feeding on bacterial growth may occur, described as 'gardening' (Hylleberg 1975, Dobbs \& Whitlatch 1982). Partly due to a lack of quantitative evidence, and partly because of a rather stringent definition that confines the gardening concept to considering only energy flow in macrofauna, current evidence for 'gardening' phenomena has however been questioned (Jumars et al. 1990, Plante et al. 1990).

Plante et al. (1989) have suggested that the rapid bacterial growth detected in the hindgut of an arenicolid polychaete is a widespread phenomenon with major biogeochemical implications. Biochemical activities (mineralization of $\mathrm{C}_{\text {org }}$, activities of hydrolytic enzymes) in burrows of Arenicola marina peaked at the burrow walls and were, with one notable exception (protease), reduced in fecal casts (Reichardt 1988). Notwithstanding the importance of the fate of sediment bacteria in the digestive tract of Arenicola marina, we suggest that entire burrow systems should be considered in order to evaluate the impact of bulk sediment feeders on biogeochemical processes in sediments. With the so-called 'feeding pockets' (Reise 1985), this is a fairly complicated particle transport system.

Distribution patterns of bacterial biomass in the burrows of deposit feeders (Dobbs \& Guckert 1988a, b, 
Alongi 1985) can provide clues regarding biogeochemically active matrices in bioturbated sediment and fauna-dependent selection of bacterial groups. However, to understand the impact of subsurface deposit feeding on turnover of bacterial biomass, feeding experiments are indispensable.

This paper is a first account of in situ bacteriological experiments focussing on burrows of Arenicola marina as transport systems for sediment particles and bacteria. It is shown that despite a high digestive efficiency in certain compartments there are also sites of bacterial enrichment.

\section{MATERIAL AND METHODS}

Study sites were situated on Westerhever Sand, an intertidal sand flat off the Eiderstedt peninsula (Germany) in the North Frisian Wadden Sea (North Sea; $54^{\circ} 22.0^{\prime} \mathrm{N}, 8^{\circ} 38.4^{\prime} \mathrm{E}$ ). Samples were obtained in summer 1989 at low tide. Burrows of Arenicola marina were completely dug out using a box corer as described by Ziegelmeier (1964)

Worms inhabiting the burrows were dissected immediately after sampling. Sediment samples were obtained aseptically from 6 locations within the burrow and digestive tract of the polychaete (Fig. 1). The 'input' region was represented by the bottom layer of the funnel, 1 to $2 \mathrm{~cm}$ below the sediment surface, $(F)$, the center of the 'feeding pocket' at the lower end of the head shaft extending from the funnel into deeper sediment layers (FP), and the content of the oesophagus (foregut) removed after dissection (FG). The output' region was represented by the content of the hindgut (HG) and one sample each from 'fresh' $(<1$ to $2 \mathrm{~h}$ old; C1) and 'aged' fecal casts ( 2 to $4 \mathrm{~h}$ old; $\mathrm{C} 2$ ).

The sediment samples were collected in cut-off $1 \mathrm{~cm}^{3}$ syringes. Samples of $0.1 \mathrm{~cm}^{3}\left(0.05 \mathrm{~cm}^{3}\right.$ of gut contents) were transferred to $2 \mathrm{~cm}^{3}$ Eppendorf vials containing $1 \mathrm{~cm}^{3}$ of 0.2 um membrane filtered artificial seawater (ASW, $\mathrm{S}=25$ ) and cooled $\left(5^{\circ} \mathrm{C}\right.$ ). Samples for epifluorescence microscopy were fixed with $4 \%$ formaldehyde (final concentration). Plate count assays were prepared in the laboratory within 30 to $40 \mathrm{~min}$ of sampling.

Feeding experiments. The particle transport capacity of single burrow systems was measured over the entire input-output distance using fluorescent particles ('luminophores', 63 um; Mahaut \& Graf 1987). Using a $1 \mathrm{~cm}^{3}$ syringe, these were injected $1 \mathrm{~cm}$ below the funnel surface, and their re-appearance in fecal casts was examined using a battery-powered fluorescent lamp.

In feeding experiments, existing fecal casts were removed during low tide, and the burrow outputs were covered with a plexiglass tube $(5 \mathrm{~cm}$ diameter) in which fecal casts produced during high tide were collected. Fluorochrome-labelled, killed bacteria were fed into the funnel of a burrow. For this purpose, culture suspensions of a bacterial isolate (gram-negative rod. $1.2 \times 1.7 u \mathrm{~m})$ were killed in $4 \%$ formaldehyde, stained with acridine orange, and rinsed 10 times with $100 \mathrm{ml}$ of sterile seawater. Using a $1 \mathrm{~cm}^{3}$ syringe, $0.9 \mathrm{ml}$ aliquots of a suspension concentrated by centrifugation to between $10^{12}$ and $10^{13}$ cells $1^{-1}$ were injected together with $0.1 \mathrm{ml}$ of a suspension $\left(10^{12}\right.$ to $\left.10^{13} \mathrm{l}^{-1}\right)$ of fluorescent latex microspheres (diameter 0.7 to $0.8 \mu \mathrm{m}$; 'Fluoresbrites', Polysciences Inc.) $1 \mathrm{~cm}$ below the surface of each funnel. The microspheres were used to trace the transport of bacteria-sized indigestible particles through a burrow system. Due to their much brighter fluorescence, these microspheres could easily be distinguished from the acridine orange-labelled bacteria.

Direct counts. Acridine orange direct counts (AODC) were determined in sonicated $(3 \times 5 \mathrm{~s}$ at $100 \mathrm{~W}$, Labsonic 1510) sediment suspensions (Hobbie et al. 1977, Meyer-Reil et al. 1978, Reichardt 1988). Samples filtered onto 0.2 um Nuclepore filters were treated with $1 \mathrm{~N} \mathrm{HCl}$ for $5 \mathrm{~min}$ prior to staining to improve penetration of the dye $0.1 \%$ acridine orange (Reichardt unpubl.). Microscopic analyses were carried out with a Leitz Dialux 20 epifluorescence microscope equipped with filter system I2 (BP 450-490 and LP 515) and oil immersion objective NPL Fluotar 100. Using a counting grid $\left(2464 \mu \mathrm{m}^{2}\right)$, bacterial densities were calculated from ca 600 cells in 60 fields of view. Only cells larger than $0.21 \mu \mathrm{m}$ were considered for counting.

Estimates of bacterial biomass were based on microscopic measurements of individual cells by recording length ( $\mathrm{L}$ ) and width (W) of given size classes using a 'New Porton' grid (May 1965). Volumes (V) of individual cells were calculated according to the formula:

$$
V=(\pi / 4) \times W^{2} \times(L-W / 3) \quad(\text { Bratbak 1985). }
$$

Total biovolumes of bacteria per $\mathrm{cm}^{3}$ of sediment were obtained by multiplication of the mean cell volumes of 60 cells by the pertinent AODC per $\mathrm{cm}^{3}$. Biomass estimates were calculated as bacterial carbon concentrations based on a conversion factor of $3.0 \times 10^{-13} \mathrm{~g} \mathrm{C}$ $u \mathrm{~m}^{-3}$ (Børsheim et al. 1990).

Viable counts. Plate counts of aerobic heterotrophic bacteria were obtained on a marine agar containing $0.7 \mathrm{~g}$ of Bacto peptone, $0.2 \mathrm{~g}$ of glucose, $0.1 \mathrm{~g}$ of yeast extract and $15 \mathrm{~g}$ of agar in $1 \mathrm{l}$ of artificial seawater $(\mathrm{S}=$ 25). Using a spread plate technique, $0.1 \mathrm{ml}$ aliquots of serial dilutions of sediment suspensions were applied in triplicate. Colony forming units (CFUs) were determined after $14 \mathrm{~d}$ of incubation at $20^{\circ} \mathrm{C}$. 
Fig. 1. Cross section of a burrow of Arenicola marina with 3 sampling sites each on ingestive side [funnel ( $F$ ), feeding pocket (FP), and foregut (FG)] and on egestive side [hindgut ( $\mathrm{HG}$ ) and successive fecal casts $(\mathrm{C} 1, \mathrm{C} 2)\}$

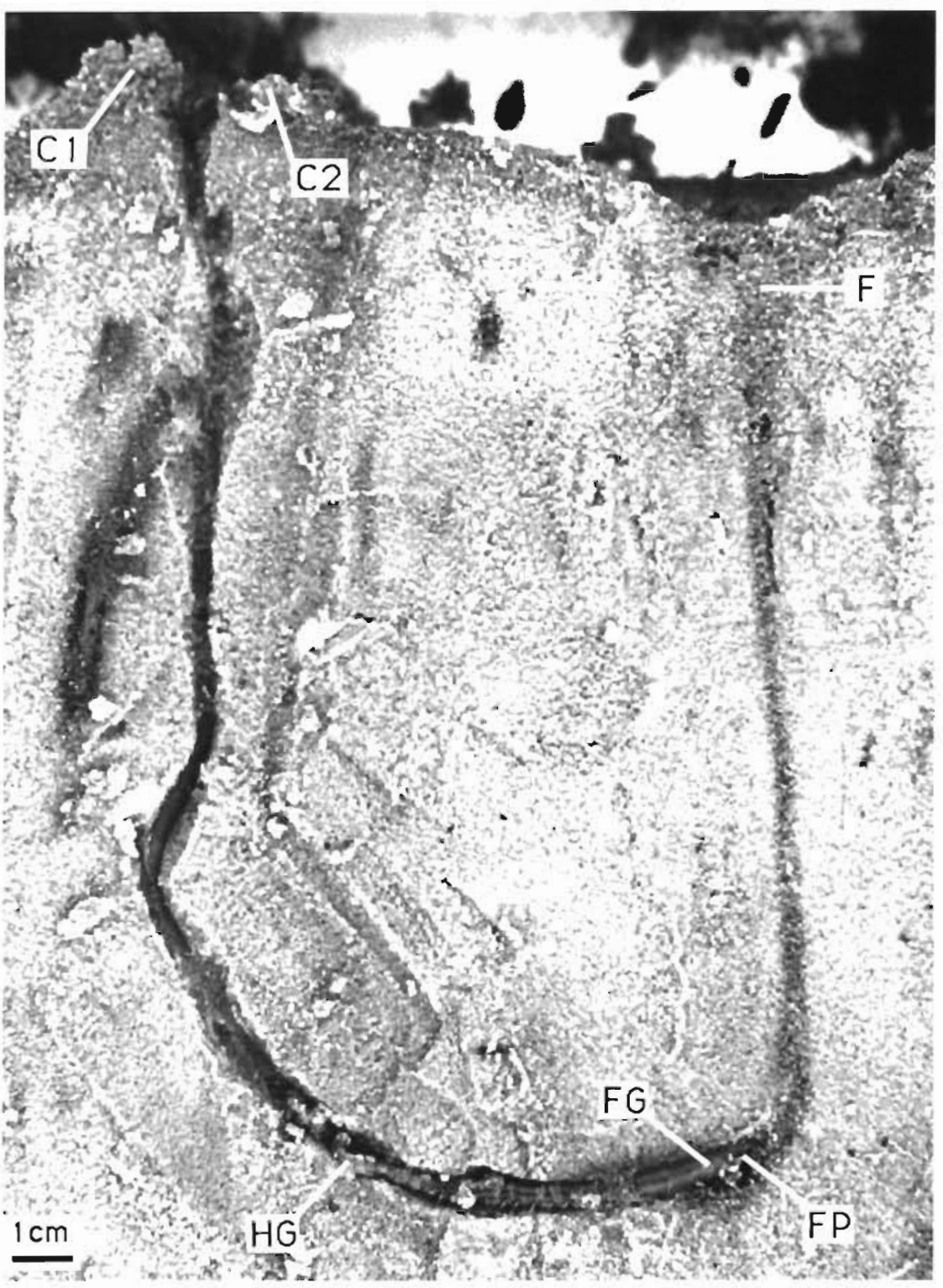

To determine CFUs of Cytophaga-like bacteria ('CLB'; Reichardt et al. 1983) on the same agar, yelloworange pigmented colonies were subject to microscopic checks of cell morphology.

Lysozyme activity. The presence of lysozyme activity in the intestinal tract of Arenicola marna was tested by lytic response of Micrococcus luteus cells (Shugar 1952). Immediately after dissecting $A$. manna. stomach and gut were extracted with $3 \mathrm{ml}$ of ice-cold $0.2 \mathrm{M}$ tns$\mathrm{HCl}$ buffer, $\mathrm{pH} 7.2$, containing $2 \%$ of triton X-100. After centrifugation ( $15 \mathrm{~min}$ at $2800 \times \mathrm{g}$ ), 50 and $100 \mu \mathrm{l}$ aliquots of the supernatant were added to $3 \mathrm{ml}$ of a suspension of $M$. luteus cells in $0.2 \mathrm{M}$ trus- $\mathrm{HCl}$ buffer. $\mathrm{pH} 7.2$, with optical densities (450 nm) of 0.55 and 0.85 , respectively. The decrease of extinction was recorded for 5 min at $20^{\circ} \mathrm{C}$. Blank assays were carned out with both extracting buffer and autoclaved gut extracts.

\section{RESULTS}

\section{Distribution patterns (AODC)}

In 5 burrow systems of Arenicola marina total bac-

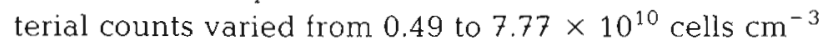
(Fig 2). Differences of bacterial cell densities in foregut (oesophagus) and hindgut indicated significant removal of bactera during gut passage (Student's $t$ test, $\mathrm{p}=0.001$ ). Also, increases of bacterial abundance from 'feeding pocket' to foregut as noted in Burrows 2 to 5 were significant ( $t$-test, $\mathrm{p}=0.001$ ). Funnel and 'feeding pocket' contained bactenal abundances of approximately the same order of magnitude. Having reached their minımum in hindgut sediment, cell counts began to recover in the fecal casts.

Covering a range from 128 to $2277 \mu \mathrm{g} \mathrm{C} \mathrm{cm}{ }^{-3}$, the 


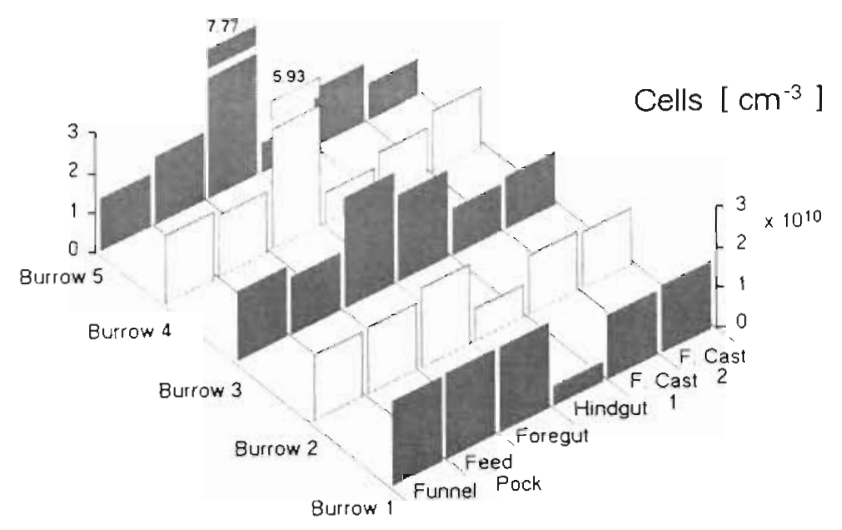

Fig. 2. Bacterial cell densities in funnel, feeding pocket, foregut, hindgut, and fecal casts of 5 burrow systems

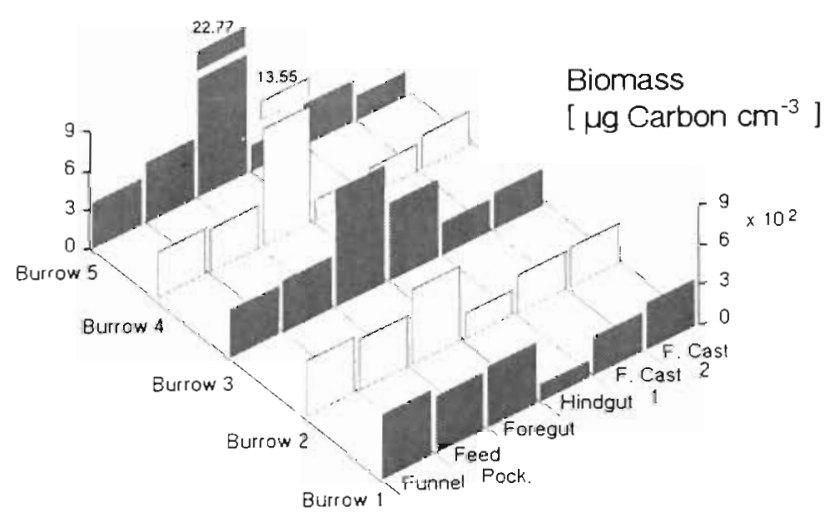

Fig. 3. Total bacterial biomass in burrow systems. Further details as in Fig. 2

distribution pattern of bacterial biomass was similar to that of bacterial cell densities (Fig. 3). Between foregut and hindgut a significant $(p=0.05$ ) decrease of 30 to $90 \%$ (mean. $70 \%$ ) was noted. Foregut samples contained greatest bacterial biomass, up to 4 - or 5 -fold that of the 'feeding pocket' samples. To obtain an estimate of the statistical significance, the impact of error propagation on confidence intervals of biomass estimates $\left(C_{B}\right)$ was accounted for by using the formula: $C_{B}=\left[X_{S}\right.$ $\left.\times C_{C}\right]+\left[X_{C} \times C_{S}\right]$, with $X_{S}$ and $X_{C}$ representing the mean values of cell sizes and cell counts, respectively, and $C_{S}$ and $C_{C}$ their confidence intervals (Sokal \& Rohlf 1981)

Within and among individual burrows, concentrations of bacterial biomass in funnel and feeding pockets' were not significantly different $(p=0.05)$. In comparison with the hindgut, concentrations of bacterial biomass in samples from the fecal casts were enhanced except in one burrow (\#3) and not significantly different $(p=0.05)$ from bacterial biomass in funnel samples.

Over the entire burrow system, masses of individual bacteria varied from 1.5 to $263.4 \mathrm{fg} \mathrm{C}$ cell $^{-1}$ (mean:
$23.4 \mathrm{fg} \mathrm{C}$ cell $\left.^{-1}\right)$. Mean values of individual cell masses at the 6 selected sites in the burrow system indicated no significant ( $t$-test, $\mathrm{p}=0.05$ ) differences.

\section{Feeding experiments}

Fluorescent particles (luminophores) which had been injected into burrow funnels of Arenicola marina reappeared in fresh fecal casts at the next low tide. This meant that during one tidal cycle particles were transported over the entire input-output distance. The same applied to bacteria-sized microspheres that had been injected into the funnel together with the fluorochrome-labelled bacteria. These microspheres were distributed throughout the burrow system and accumulated in the foregut and the fecal casts (Fig. 4A).

Similar distribution patterns were noted for the biomass of injected bacterial cells in the input region, but not in the output region of the burrows (Fig. 4B). The ratio $\mathrm{B} / \mathrm{A}$ of labelled bacteria to microspheres showed an almost continuous decrease from the funnel to the fecal casts (Fig. 4C). Differences between foregut and hindgut as well as between hindgut and fecal casts were significant $(p=0.05)$. Between foregut and fecal casts the relative portion of bacteria as indicated by the

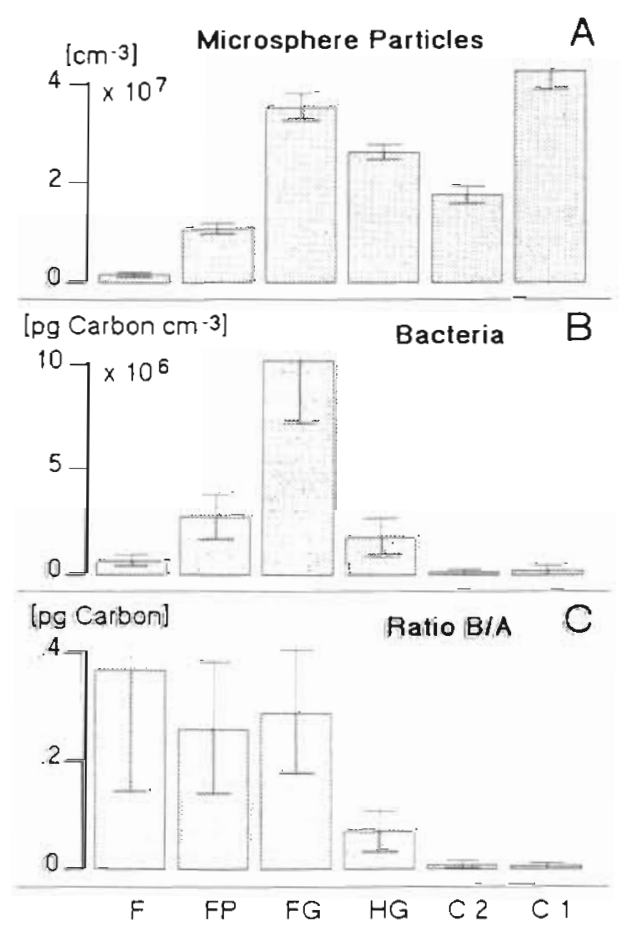

Fig. 4. In situ feeding experiment. Distribution patterns obtained following one tidal cycle for (A.) microspheres and (B) labelled bacteria. (C) Proportions of bacteria to undigestible microspheres. Bars indicate confidence limits $(p=0.05)$. Further abbreviations as in Fig. 1 


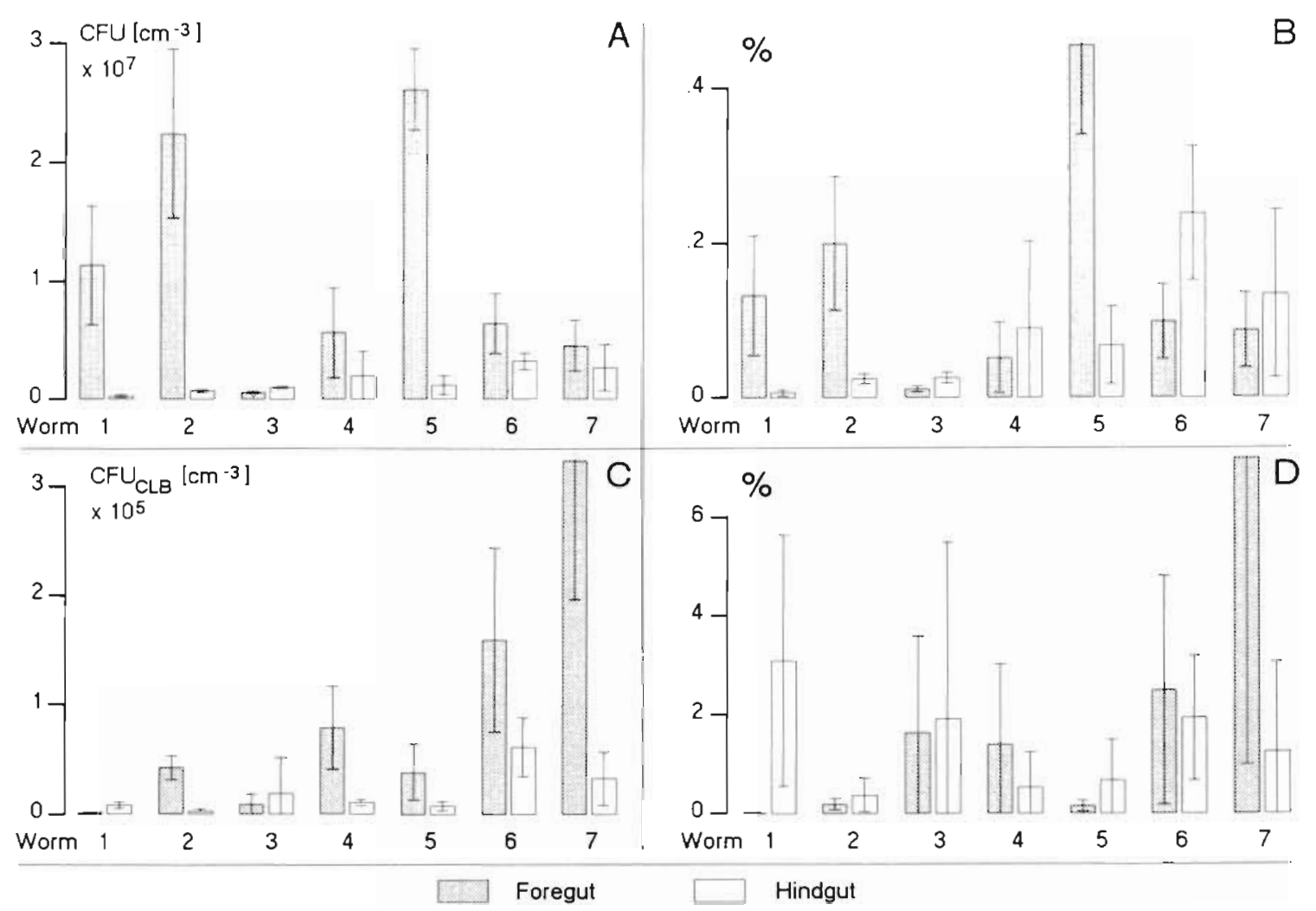

Fig. 5. Arenicola marina. Distribution of viable counts (CFU) of aerobic heterotrophic bacteria in foregut and hindgut of 7 specimens. Top: (A) absolute and (B) relative abundance of total CFUs (relative to AODC). Bottom: (C) absolute and (D) relative abundance of Cytophaga-like bacteria ( $C F U_{C L B}$, relative to total $\left.C F U\right)$. Bars indicate confidence limits $(p=0.05)$

ratio $\mathrm{B} / \mathrm{A}$ had been reduced by more than $95 \%$. A slight increase of the ratio from 'feeding pocket' to foregut was not significant.

\section{Viable counts of ingested bacteria}

Gut passage in Arenicola marina affected the ability of ingested sediment bacteria to form macrocolonies, as indicated by viable counts (CFUs) in foregut and hindgut samples (Fig. 5A to D). CFUs of most gut contents analysed were reduced in the hindgut by up to $95 \%$ (Fig. 5A). This reduction was significant in 3 burrows (\# 1,2 and $5, \mathrm{p}=0.05$ ). As percentage of total bacterial counts, CFUs did not exceed $1 \%$ of $\mathrm{AODC}$ (Fig. 5B). In single paired samples, decreases $(\# 1,2,5)$ as well as increases (\# 3, 4, 6, 7) of these relative CFUs in the hindgut were noted. This result indicated positive as well as negative effects of gut transit on the viability of sediment bacteria.

Like total CFUs (Fig. 5A), CFUs obtained for Cytophaga-like bacteria ( $\mathrm{CFU}_{\mathrm{CLB}}$ ) were mostly reduced in the hindgut (Fig. $5 \mathrm{C}$ ). The relative proportion of $\mathrm{CFU}_{\mathrm{CLB}}$ among total CFUs varied from 0.02 to $7 \%$
(Fig. 5D) and, like the percentage of total CFUs, showed varying responses to gut transit (Fig. 5D). An apparent inverse trend between the relative proportions of aerobic heterotrophs and Cytophaga-like bacteria that could be inferred from a comparison of Fig. 5B \& D turned out to be statistically insignificant at the $5 \%$ level.

Gut extracts of Arenicola marina contained bacteriolytic enzymes. In $100 \mu \mathrm{l}$ of gut extract, lysozyme activity was equivalent to lysis of $8.9 \times 10^{6}$ Micrococcus luteus cells min $^{-1}$. Blank assays, carried out with both extracting buffer and autoclaved gut extract, did not change the optical density of the assay suspension during testing periods of 5 min (Fig. 6).

\section{DISCUSSION}

\section{Digestion of sediment bacteria}

Removal of ingested bacteria may result from mechanical agitation during gut passage and be completed by endogenous or acquired digestive enzymes. For example, Arenicola marina produces an extremely 


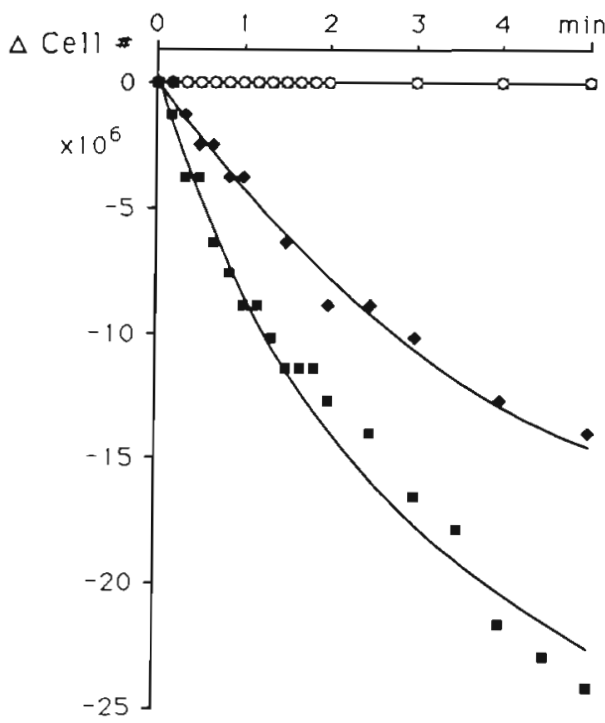

Fig. 6. Arenicola marina. Assay for lysozyme activity. Timedependent decrease of cell density ( $\Delta$ cell \#, based on optical density measurements) of Micrococcus luteus suspension in the presence of $50(\bullet)$ and $100 \mu \mathrm{l}(\boldsymbol{\bullet})$ of gut extract. $(\diamond)$ Blank value obtained with extracting buffer; (a) blank value obtained with autoclaved gut extract

stable protease (Longbottom 1970, Eberhardt 1989). Above all, however, enzymes attacking bacterial cell walls (lysozyme) are likely to cause the most efficient destruction of sediment bacteria. There seems to be no previous evidence for bacteriolytic activity in the intestinal tract of Arenicola spp. We do not know whether the enzyme is produced by the polychaete or only acquired from its gut microflora.

The feeding experiments with fluorochrome-labelled, killed bacteria confirm that ingested bacteria are efficiently removed from the sediment. Similar efficiencies of digestive removal of bacteria on the order of 70 to $90 \%$ or more are known for other aquatic detritivores (Baker \& Bradnam 1976, Harper et al. 1981, Lopez \& Levinton 1987).

This efficiency of digestive removal of bacteria must not be confused with assimilation efficiency. The latter is not known for Arenicola marina, but may reach $70 \%$ in other benthic detritivores (Harvey \& Luoma 1984, Lopez \& Levinton 1987). As rates of digestive removal set the upper limit for assimilation rates, predictions of the potential importance of bacterivory for the energy budget of a deposit feeder are possible. According to Plante et al. (1989), Abarenicola vagabunda can digest and assimilate not more than $48 \mu \mathrm{g}$ bacterial $\mathrm{C} \mathrm{d}^{-1}$, equal to only $5 \%$ of its total carbon requirement. Our results suggest a different scenario for Arenicola marina, which can remove $3.1 \times 10^{10}$ bacterial cells or $850 \mu \mathrm{g}$ bacterial $\mathrm{C} \mathrm{h}^{-1}$ (corresponding to the mean difference in bacterial biomass between foregut and hindgut in Fig. 3). We consider that this remarkable difference reflects interspecific differences more than differences in techniques employed to determine bacterial biomass. The detection limit for bacteria counted on $0.4 \mu \mathrm{m}$ Nuclepore filters (Plante et al. 1989) is only ca $25 \%$ lower than in our study using $0.2 \mu \mathrm{m}$ filters. This methodological difference is far less than the observed difference in carbon removal rates.

\section{A case of 'gardening'?}

When comparing the distribution patterns of bacterial biomass in the burrow system with the results obtained in the feeding experiments, certain differences deserve attention. Whereas non-manipulated burrow systems were characterized by a significant peak of bacterial biomass in the oesophagus region, this maximum was not apparent in the feeding experiments using killed bacterial cells (proportional counts as shown in Fig. $4 \mathrm{C}$ ). In nature, bacteria may accumulate in the foregut by active enrichment (growth) rather than by any passive or external forces. Bacterial enrichment in sediment from the foregut (oesophagus) region is consonant with the high concentration of organic matter found there (Krüger 1959, cited in Hylleberg 1975). It supports Hylleberg's (1975) concept of gardening which was based on organic enrichment in the pocket sand of Abarenicola pacifica. However, convincing evidence for this concept had to be considered as lacking, until ingestion of bacteria by a deposit feeder could be proved to follow their growth enhancement by the animal (Plante et al. 1990). Our data on Arenicola marina suggest that such a sequence of events does occur.

It appears necessary to clarify the meaning of 'gardening'. Those authors who criticize that there is not enough evidence for 'gardening' use this term in its strict sense of microbial growth being directly tapped by an animal whose fitness is improved in this way (Plante et al. 1990). On the other hand, there is ample evidence for stimulation of epizoic and perizoic bacterial growth by benthic macroinvertebrates (e.g. Alongi 1985, Dobbs \& Guckert 1988a, Reichardt 1988, Bussmann \& Reichardt 1990). From a microbiologist's point of view any growth-promoting effect of burrowing macrofauna on copiotrophic sediment bacteria is aptly characterized by a term like 'gardening' without anticipating the existence of any role of those bacteria in the energy budget of the animal. Moreover, in terms like 'kitchen garden(ing)' (Fenchel \& Finlay 1989), the anthropocentric metaphor may be easily specified, wherever applicable. 


\section{Effects on composition of sediment microflora}

It can be concluded that the burrow system of Arenicola marina, with the polychaete gut as its 'nucleus', can achieve both enrichment and removal of sediment bacteria. In sediments bioturbated by this polychaete or other subsurface deposit feeders, certain biogeochemical processes are intensified (Hines et al. 1982, Holdren \& Armstrong 1982, Henriksen et al. 1983, Sayama \& Kurihara 1983, Reichardt 1988, 1989, Doering 1989). Despite general agreement about stimulatory effects on bacterial activities, the role of bioturbation in microbial dynamics is still considered as ambiguous (Krantzberg 1985). To resolve this inconclusiveness, it is important to find out to what extent the composition of sediment microbiota (populations as well as physiologically defined categories) is affected by a particular deposit feeder. In relatively few cases so far have qualitative changes within the sediment microflora been ascribed to benthic deposit feeders (Wavre \& Brinkhurst 1971, Austin \& Baker 1988, Dobbs \& Guckert 1988a, Reichardt 1989).

Sediment egested by the enteropneust worm Ptychodera bahamensis, a funnel feeder like Arenicola marina, contains $30 \%$ less viable microbial biomass than sediment from its funnel. Certain biomarker fatty acids, however, do not follow this general decrease after gut passage, suggesting that certain bacterial populations can escape digestion (Dobbs \& Guckert 1988b). Selective digestion and survival of bacteria has already been suggested for Aeromonas and other bacteria ingested by freshwater oligochaetes (Wavre \& Brinkhurst 1971). In the case of insect larvae, ingested Flavobacterium spp. can avoid digestion during gut transit by attachment to the hindgut wall (Austin \& Baker 1988). The only bacterial groups analysed separately in the present investigation were easily detectable Cytophaga-like bacteria (CLB) comprising Cytophaga, Flexibacter and Flavobacterium spp. (Reichardt et al. 1983). With high variances between individual pairs of foregut and hindgut samples, there was no clear indication of enrichment or growth of viable bacteria in the hindgut as noted for Abarenicola vagabunda (Plante et al. 1989). Long retention times of members of the CLB-group in the gut as noted by Wavre \& Brinkhurst (1971) and Austin \& Baker (1988) cannot be ruled out. Production of lysozyme by many CLB (Reichardt et al. 1983) is likely to augment the capacity of the animal's gut to digest bacteria.

\section{Regrowth and rapid turnover}

Such drastic removal of sediment bacteria in the gut of the predominant and most efficient deposit feeder in the study area must be compensated for, if bacteriamediated nutrient cycling is to be maintained. Apparently, the gut of arenicolid polychaetes can function as digester and culturing system at the same time. Generation times of $1 \mathrm{~h}$ for ingested bacteria surviving digestion in Abarenicola vagabunda have been estimated (Plante et al. 1989). On the other hand digestive removal by Arenicola marina may reach ca $1.2 \times 10^{11}$ cells $\mathrm{cm}^{-3} \mathrm{~h}^{-1}$ assuming an average residence time in the gut of 15 min (Kermack 1955) and an average gut content of $0.25 \mathrm{~cm}^{3}$. This removal rate exceeds average estimates of bacterial production in marine sediments (on the order of $10^{8}$ cells $\mathrm{cm}^{-3} \mathrm{~h}^{-1}$ or much lower; Moriarty \& Pollard 1981, Fallon et al. 1983, Reichardt 1988, Austin \& Findlay 1989).

\section{Biogeochemical consequences}

Evidence for enhanced bacterial densities at macrofaunal burrows and other bioturbate structures may be positive (Aller \& Yingst 1978, Lopez et al, 1979, Dobbs \& Whitlatch 1982, Dobbs \& Guckert 1988a, b) or negative (Hines et al. 1982, Alongi 1985, Reichardt 1988, 1989). In all these cases, however, a stimulation of certain biogeochemical activities has been noted. To what extent sediment feeding favors certain biogeochemical pathways can only be speculated on. Stimulation of subsurface nitrification rates (Reichardt 1989) may be explained simply by chemoautotrophic utilization of ammonia excreted from echiurians (Smith et al. 1986) without involvement of these bacteria in the nutrition of that infauna. In other cases, though, it appears most likely that deposit feeding has a selective impact on biocatalytic activities (Hargrave 1970, Juniper 1981, Hines et al. 1982, Hines \& Jones 1985).

Acknowledgements. These investigations were supported by a grant from Deutsche Forschungsgemeinschaft (Re 271/ 18-1). We thank 3 anonymous reviewers for their valuable criticism

\section{LITERATURE CITED}

Aller, R. C., Yingst, J. Y (1978). Biogeochemistry of tubedwellings: a study of the sedimentary polychaete Amphitrite ornata (Leidy). J. mar Res. 36: 201-254

Alongi, D. M. (1985). Microbes, meiofauna, and bacterial productivity on tubes constructed by the polychaete Capitella capitata. Mar. Ecol. Prog. Ser 23: 207-208

Austin, D. A., Baker, J. H. (1988). Fate of bacteria ingested by larvae of the freshwater mayfly Ephemera danica. Microb. Ecol. 15: 323-332

Austin, H. K., Findlay, S. E. G. (1989). Benthic bacterial biomass and production in the Hudson River estuary. Microb. Ecol. 18: 105-116

Baker, J. H., Bradnam, L. A. (1976). The role of bacteria in the nutrition of aquatic invertebrates. Oecologia 24: 95-104 
Børsheim, K. Y., Bratbak, G., Heldal, M. (1990). Enumeration and biomass estimation of planktonic bacteria and viruses by transmission electron microscopy. Appl. environ. Microbiol. 56: 352-356

Bratbak, G. (1985). Bacterial biovolume and biomass estimations. Appl. environ. Microbiol. 49: 1488-1493

Bussmann, I., Reichardt, W. (1990). Bacteria associated with marine bivalves during survival under anoxic conditions. In: Lesel, R. (ed.) Microbiology in poecilotherms. Elsevier Science Publishers, Amsterdam, p. 163-167

Cadee, G. C. (1976). Sediment reworking by Arenicola marina on tidal flats in the Dutch Wadden Sea. Neth. J. Sea Res. 10: $440-460$

Deming, J. W., Colwell, R. R. (1982). Barophilic bacteria associated with digestive tracts of abyssal holothurians. Appl. environ. Microbiol. 44, 1222-1230

Dobbs, F. C., Guckert, J. B. (1988a). Callianassa trilobata (Crustacea: Thalassinidea) influences abundance of meiofauna and biomass, composition, and physiological state of microbial communities within its burrow. Mar. Ecol. Prog. Ser 45: 69-79

Dobbs, F. C., Guckert, J. B. (1988b). Microbial food resources of the macrofaunal deposit feeder Ptychodera bahamensis (Hemichordata: Enteropneusta). Mar. Ecol. Prog. Ser. 45: $127-136$

Dobbs, F. C. Whitlatch, R. B. (1982). Aspects of deposit feeding by the polychaete Clymenella torquata. Ophelia 21: 159-166

Doering, P. H. (1989). On the contribution of the benthos to pelagic production. J. mar. Res. 47: 371-383

Eberhardt, J. (1989). Die Verdauungsproteinasen des Wattwurms Arenicola marina (Polychaeta) - Enzyme von extremer Stabilität. Verh. dt. Zool. Ges. 82: 298

Fallon, R. D., Newell, S. Y., Hopkinson, C. S. (1983). Bacterial production in marine sediments: will cell-specitic measures agree with whole-system metabolism? Mar. Ecol. Prog. Ser 11. 119-127

Fenchel, T., Finlay, B. J. (1989). Kentrophoros: a mouthless ciliate with a symbiotic kitchen garden. Ophelia 30: 75-93

Hargrave, B. T (1970). The effect of a deposit-feeding amphipod on the metabolism of benthic microflora. Limnol. Oceanogr. 15: 21-30

Harper, R. M., Fry, J. C., Learner, M. A. (1981). A bacteriological investigation to elucidate the feeding biology of Nais variabilis (Oligochaeta: Naididae). Freshwater Biol. 11 $227-236$

Harvey, R. W., Luoma, S. N. (1984). The role of bacterial exopolymer and suspended bacteria in the nutrition of the deposit-feeding clam. Macoma balthica. J. mar Res. 42 $957-968$

Henriksen, K., Rasmussen, M. B., Jensen, A. (1983). Effect of bioturbation on microbial nitrogen transformation in the sediment and flux of ammonium and nitrate to the overlying water. Ecol. Bull. (Stockholm) 35: 193-205

Hines, M. E., Jones, G. E. (1985). Microbial biogeochemistry and bioturbation in the sediments of Great Bay, New Hampshire. Estuar coast. Shelf Sci. 20: 729-742

Hines, M. E., Orem, W. H., Lyons, W. B., Jones, G. E. (1982). Microbial activity and bioturbation-induced oscillations in pore water chemistry of estuarine sediments in spring. Nature, Lond. 299: 433-435

Holdren, G. C., Armstrong, D. E. (1982). Factors affecting phosphorus release from intact sediment cores. Environ. Sci. Technol. 14: 79-87

Hobbie, J. E., Daley, R. J., Jasper, S. (1977). Use of Nuclepore filters for counting bacteria by fluorescence microscopy Appl environ. Microbiol. 33: 1225-1228
Hylleberg, J. (1975). Selective feeding by Abarenicola pacifica with notes on Abarenicola vagabunda and a concept of gardening in lugworms. Ophelia 14: 113-137

Jumars, P. A., Mayer, L. M., Deming, J. W., Baross, J. A. Wheatcroft, R. A. (1990). Deep-sea deposit-feeding strategies suggested by environmental and feeding constraints. Phil. Trans. R. Soc. Lond. A 331: 85-101

Juniper, S. K. (1981). Stimulation of bacterial activity by a deposit feeder in two New Zealand intertidal inlets. Bull. mar. Sci. 31: 691-701

Kermack, D. M. (1955). The anatomy and physiology of the gut of the polychaete Arenicola marina (L). Proc. Zool. Soc. Lond. 125: 347-381

Krantzberg, G. (1985). The influence of bioturbation on physical, chemical and biological parameters in aquatic environments: a review. Environ. Pollut. (Ser. A) 39: 99-122

Krüger, F. (1959). Zur Ernährungsphysiologie von Arenicola marina L. Verh. dt. Zool. Ges. 52: 115-120

Longbottom, M. R. (1970). Distributions of the digestive enzymes in the gut of Arenicola marina. J. mar biol. Ass. U.K. 50: 121-128

Lopez, G. R., Levinton, J. S. (1987). Ecology of deposit-feeding animals in marine sediments. Q. Rev. Biol. 62: 235-260

Lopez, G. R., Riemann, F., Schrage, M. (1979). Feeding biology of the brackish-water oncholaimid nematode Adoncholaimus thalassophygas. Mar. Biol. 54: 311-318

Mahaut, M. L., Graf, G. (1987). A luminophore tracer technique for bioturbation studies. Oceanologica Acta 10: $323-328$

May, K. R. (1965). A new graticule for particle counting and sizing. J. sci. Instrum. 42: 500-501

Meyer-Reil, L. A., Dawson, R., Liebezeit, G., Tiedge, H. (1978). Fluctuations and interactions of bacterial activity in sandy sediments and overlying waters, Mar. Biol, 48: 161-171

Moriarty, D. J. W., Pollard, P. C. (1981). DNA synthesis as a measure of bacterial productivity in seagrass sediments Mar. Ecol. Prog. Ser. 5: 151-156

Newell, R. C. (1965). The role of detritus in the nutrition of two marine deposit feeders, the prosobranch Hydrobia ulvae and the bivalve Macoma balthica. Proc. Zool. Soc. Lond 144: $25-45$

Plante, C. J., Jumars, P. A., Baross, J. A. (1989). Rapid growth in the hindgut of a marine deposit feeder. Microb. Ecol. 18 $29-44$

Plante, C. J., Jumars, P. A., Baross, J. A. (1990). Digestive associations between marine detritovores and bacteria Ann. Rev. Ecol. Syst. 21: 93-127

Reichardt, W. (1988). Impact of bioturbation by Arenicola marina on microbiological parameters in intertidal sediments. Mar Ecol. Prog. Ser. 44: 149-158

Reichardt. W. (1989). Microbiological aspects of bioturbation. Scient. Mar. 53: 301-306

Reichardt, W., Gunn, B., Colwell, R. R. (1983). Ecology and taxonomy of chitinoclastic Cytophaga and related chitindegrading bacteria isolated from an estuary. Microb. Ecol. 9: $273-294$

Reise, K. (1985). Tidal flat ecology. An experimental approach to species interactions. Springer Verlag, Berlin, p. 127

Sayama, M., Kurihara, Y (1983). Relationship between burrowing activity of the polychaetous annelid, Neanthes japonica (Izuka) and nitrification and denitrification processes in the sediments. J. exp. mar. Biol. Ecol. 72: 233-241

Shugar, D. (1952). The measurement of lysozyme activity and the ultraviolet inactivation of lysozyme. Biochim. Biophys. Acta 8: 302-309

Smith, C. R., Jumars, P. A., Demaster, D. J. (1986). In situ 
studies of megafaunal mounds indicate rapid sediment turnover and community response at the deep-sea floor. Nature, Lond. 323: 251-253

Sokal, R. R., Rohlf, F. J. (1981). Biometry, 2nd edn. Freeman and Co., San Francisco

Wavre, M., Brinkhurst, R. O. (1971). Interactions between

This article was submitted to the editor some tubificid oligochaetes and bacteria found in the sediments of Toronto Harbour, Ontario. J. Fish. Res. Bd Can 28: $335-341$

Ziegelmeier, E. (1964). Uber die Wohnbau-Form von Arenicola marina L. Helgoländer wiss. Meeresunters. 11; $157-160$

Manuscript first received: January 30, 1991

Revised version accepted: August 20, 1991 